\title{
KONSEP PERANAN LAKI-LAKI DAN PEREMPUAN
}

\section{Erniati}

\begin{abstract}
The concept of the roles of men and women basically has the right to obtain gender justice, especially to women. Gender justice is meant is the degree and equal position between men and women in society to carry out activities in various fields such as the field of work in particular. So the concept of gender is that women can gain freedom to move outside the home such as studying, working as an office employee without any pressure so that women will have the same degree as men and there is no oppression against women anymore.
\end{abstract}

Keywords: Role Concepts, Men, Women.

\section{PENDAHULUAN}

Gender merupakan perbedaan jenis kelamin yang bukan disebabkan oleh perbedaan biologis dan bukan kodrat Tuhan, proses sosial budaya yang panjang. Perbedaan perilaku antara laki-laki dan perempuan, selain disebabkan oleh faktor biologis sebagian besar justru terbentuk melalu proses sosial dan kultural. Gender bisa dikategorikan sebagai perangkat operasional dalam melakukan measure (pengukuran) terhadap persoalan laki-laki dan perempuan terutama yang terkait dengan pembagian peran dalam masyarakat yang dikonstruksi oleh masyarakat itu sendiri. Istilah gender telah menjadi isu penting dan sering diperbincangkan akhir-akhir ini. Banyak orang yang mempunyai persepsi bahwa gender selalu berkaitan dengan perempuan, sehingga setiap kegiatan yang bersifat perjuangan menuju kesetaraan dan keadilan gender hanya dilakukan dan diikuti oleh perempuan tanpa harus melibatkan laki-laki.

Perempuan merupakan sumber daya yang jumlahnya cukup besar, bahkan di seluruh dunia melebihi jumlah laki-laki. Namun perempuan yang yang berpartisipasi di sektor publik berada jauh di bawah laki-laki, terutama di bidang politik. Rendahnya 
320 | MUSA WA, Vol. 11 No. 2 Desember 2019 : 319 - 343

partisipasi perempuan di sektor publik bukan hanya terjadi di Indonesia, tetapi juga di seluruh dunia, termasuk juga di negara negara maju. Sebagai contoh dalam bidang pendidikan kaum perempuan masih tertinggal dibandingkan dengan laki-laki. Ketertinggalan perempuan tersebut tercermin dalam presentase perempuan buta huruf (14,47\% tahun 2001) yang lebih besar dibandingkan leki-laki $(6,87 \%)$. Data tersebut menegaskan bahwa partisipasi perempuan di sektor publik dalam bidang pendidikan masih rendah.. Contoh selanjutnya di India, di negara ini wanita dibagi menjadi tiga kelompok atau kelas, yaitu kelas atas, menengah, dan bawah. Pandangan masyarakat India terhadap wanita ditentukan pada kelas atau strata mana dia berada. Umumnya kelas atau strata tersebut dilihat dari kasta atau keturunan, selain itu juga dari kelas ekonomi. Tuntutan agar wanita terjun di dunia kerja mendorong mereka untuk memperoleh pendidikan yang lebih tinggi. Semakin tinggi pendidikan seorang wanita, semakin terangkat kelas dan derajat dia dalam masyarakat. Bagi kelas rendah, wanita dilahirkan, dirawat lalu tumbuh, harus tinggal dan bekerja di rumah., kemudian dikawinkan dalam usia belia. Artinya wanita yang tidak berpendidikan tidak mempunyai alasan untuk mencari pekerjaan yang lebih layak.

\section{PEMBAHASAN}

\section{A. Kelemahan Sebagai Kodrat Perempuan}

Konsep penting yang harus dipahami ketika berbicara tentang sosialisasi gender adalah memisahkan dua konsep utama yaitu jenis kelamin dan gender. Dengan membedakan kedua konsep yang sering disalahfahami ini maka diharapkan para orang tua dan guru mengetahui mana sesungguhnya yang kodrati dan yang bukan kodrati bagi 
laki-laki dan perempuan. Jenis kelamin merupakan pensifatan atau pembagian dua jenis kelamin manusia yang ditentukan secara biologis. Misalnya, bahwa manusia yang berjenis kelamin laki-laki memiliki penis, jakala dan memprodusi sperma. Sedangkan manusia yang berjenis kelamin perempuan memiliki alat reproduksi seperti rahim dan saluran untuk melahirkan, memproduksi telur, memiliki vagina dan alat menyusui. Secara biologis, semua yang disebutkan di atas melekat selamanya pada manusia yang berjenis kelamin laki-laki dan perempuan. Artinya, secara biologis, semua yang dimiliki dan melekat pada manusia jenis kelamin laki-laki tidak akan bisa dipertukarkan pada manusia jenis kelamin perempuan, begitu pula sebaliknya. Inilah yang dinamakan ketentuan Tuhan yang bersifat kodrati. ${ }^{1}$

Sedangkan gender adalah suatu sifat yang melekat pada kaum laki-laki dan perempuan yang dikonstruksi secara sosial maupun kultural. Misalnya, bahwa perempuan dikenal sebagai makhluk yang lemah lembut, emosional dan keibuan. Sementara laki-laki dianggap sebagai makhluk yang memiliki fisik kuat, rasional, jantan dan perkasa. Ciri dari sifat ini sendiri sebenarnya merupakan sifat-sifat yang dapat dipertukarkan. Artinya, ada laki-laki yang emosional, lemah lembut dan keibuan, sementara ada juga perempuan yang kuat, perkasa, dan lebih mengedepankan rasio daripada emosionalnya. Perubahan ciri dari sifat tersebut dapat terjadi dari waktu ke waktu, dari suatu tempat ke tempat yang lain, dan inilah yang dinamakan sesuatu yang

\footnotetext{
${ }^{1}$ Hidle Hein, "Liberating Philisophy: An End to the Dichotomy of Spirit and Matter," eds. dalam Ann Gary dan Marlyn Persall, Women, Knowledge and Reality (London: Unwin Hyman, 1989), 294.
} 
322 | MUSA WA, Vol. 11 No. 2 Desember 2019 : 319 - 343

bukan kodrati.

Indonesia merupakan salah satu negara yang sedang berada dalam perkembangan. Karena itu selalu diupayakan pembangunan di segala bidang. Untuk mensukseskan pembangunan tersebut, diperlukan sumber daya manusia yang berkualitas tinggi. Untuk menciptakan sumber daya manusia yang berkualitas tinggi, diperlukan pendidikan yang tinggi pula. Mengikutsertakan laki-laki dan perempuan dalam pembangunan, berarti memanfaatkan sumber daya insani yang potensial dalam pembangunan dan merupakan tindakan yang efisien dan efektif. Apalagi didukung dengan kualitas sumber daya manusia yang tinggi dan latar belakang pendidikan yang tinggi pula. Sumber daya manusia yang berkualitas rendah akan merupakan beban bagi pembangunan. Oleh karena itu, pendidikan mempunyai arti yang sangat penting. UUD 1945 mengamanatkan bahwa laki-laki dan perempuan mempunyai hak dan kewajiban yang sama dalam pembangunan, termasuk pembangunan di bidang pendidikan. Namun kenyataan menunjukkan bahwa perempuan mengalami ketertinggalan daripada lakilaki.

Pengkajian tentang perempuan di berbagai belahan dunia khususnya di Indonesia menunjukkan perkembangan yang cukup pesat. Hal itu terlihat pada meningkatnya intensitas diskusi, seminar dan penelitian yang menampilkan keragaman aspek yang dikaji dan metode pendekatan yang dipakai. Semua itu dilakukan sebagai bentuk refleksi akan adanya kesadaran berbagai kalangan akan pentingnya kedudukan dan keterlibatan perempuan dalam proses transformasi sosial.

Will Durant, seorang sejarawan terkemuka sebagaimana dikutip oleh Marwah 
Daud Ibrahim, pernah menulis bahwa manusia di seluruh penjuru dunia akan menyaksikan revolusi besar mulai abad ke-20. Revolusi tersebut menurutnya bukanlah revolusi politik atau militer, tetapi kebangkitan peran perempuan di berbagai bidang kehidupan. $^{2}$

Perempuan harus melakukan otonomi terhadap dirinya sendiri, Ini merupakan langkah yang harus ditempuh menuju kesetaraan dan kebebasan dari ketidakadilan. Salah satu aspek otonomi yang harus ditempuh adalah melalui "pendidikan". Pendidikan merupakan sebuah proses untuk mengembangkan potensi manusia. Pada dasarnya jiwa manusia senantiasa dinamis dan selalu bergerak aktif dalam rentang kesinambungan pada suatu titik "mengoptimalkan potensi dinamisnya". ${ }^{3}$ Perbaikan kualitas bagi setiap manusia menjadi suatu keharusan. Pendidikan menjadi hak dan sekaligus kewajiban bagi setiap manusia untuk berubah, tidak terkecuali bagi perempuan.

Keadilan untuk mendapatkan hak dan menunaikan kewajiban adalah tujuan dalam hidup. Keadilan adalah gagasan paling sentral sekaligus tujuan tertinggi yang diajarkan setiap agama dan kemanusiaan dalam upaya meraih cita-cita manusia dalam

\footnotetext{
${ }^{2}$ Lebih lanjut dijelaskan bahwa perjuangan perempuan dalam dunia modern ini, bukan sekedar untuk mendapatkan persamaan kedudukan dan hak hak semata-mata dengan kaum laki-laki, tetapi untuk lebih dapat melakukan peranannya dalam kehidupan keluarga dan masyarakat. Dapat dilihat dalam bidikan lensa masa kini tampak bahwa perempuan begitu handal menekan galaksi board merekayasa gene di laboratorium, mengintip galaksi dari lensa teleskop, mengejar dan menulis bberita untuk media massa massa, sebagian lainnya pandangan diarahkan ke manca negara, mengadu pikiran di lembaga perwakilan rakyat, merancang pesawat terbang, menjjadi dokter dan sebagainya. (Lihat Marwah Daud Ibrahim. Teknologi Emansipasi dan Transendensi: Wacana Peradaban dengan Visi Islami; Bandung: Mizan, 1994). h. 123

${ }^{3}$ Najlah Naqiyah, Otonomi Perempuan, (Cet. 2; Bayumesia Publishing: Malang, 2005), h. 131132.
} 
324 | MUSA WA, Vol. 11 No. 2 Desember 2019 : 319 - 343

kehidupan bersamanya. Abu Bakar al Razi (w. 865 M), menegaskan, "Tujuan tertinggi diciptakan dan kemana diarahkan bukanlah kegembiraan atas kesenangan fisik, tetapi pencapaian ilmu pengetahuan dan praktik keadilan.”

Dalam konteks Islam, sentralitas ide keadilan dibuktikan melalui penyebutannya di dalam Alquran lebih dari 50 kali dalam beragam bentuk. Di samping menggunakan kata $a l$ 'adl, kitab suci tersebut juga menggunakan kata lain yang maknanya identik dengan keadilan, seperti al-qist, al-wasat (tengah), al-mizan (seimbang), al-musawah (sama/persamaan), dan al-mathil (setara). Lebih dari itu keadilan menjadi nama bagi Tuhan dan tugas utama kenabian. Teks memperlihatkan bahwa ia merupakan gabungan nilai moral dan sosial yang menunjukkan kejujuran, keseimbangan, kesetaraan, kebajikan, dan kesederhanaan. Nilai moral ini menjadi inti visi agama yang harus direalisasikan manusia dalam kapasitasnya sebagai individu, keluarga, anggota komunitasnya, maupun penyelenggara negara.

Keadilan secara umum didefinisikan sebagai "menempatkan sesuatu secara proposional" dan "memberikan hak kepada pemiliknya". Definisi ini memperlihatkan sekaligus menunjukkan adanya keterkaitan dengan pemenuhan hak seseorang atas orang lain yang seharusnya diterima tanpa diminta karena hak itu ada dan menjadi miliknya.

Salah satu wujud pemunuhan atas hak dan kewajiban setiap individu adalah pendidikan. Dalam term agama, pemenuhan kebutuhan akal dan spritual dapat dilakukan dengan belajar untuk mendapatkan pengetahuan sebagai jalan untuk memahami agama dan membangun dunia. 
Pendidikan dan menuntut ilmu dalam Islam menjadi sebuah keharusan. Dalam ayat yang pertama kali turun yaitu surat al-Alaq disebutkan kata iqra' yang mempunyai makna membaca. Perintah ini menyiratkan pentingnya belajar melalui membaca untuk memahami semua fenomena yang ada di dunia. Nabi Muhammad saw juga menegaskan kembali tentang kewajiban untuk mencari ilmu tanpa membedakan jender yaitu: "talab al-ilmi faridatun 'ala kulli muslimun wa muslimatin". ${ }^{4}$ Jadi pendidikan itu secara inklusif diperuntukkan untuk laki-laki dan perempuan. Karena pada dasarnya dalam Islam, ilmu adalah suci dan mencari ataupun menuntutnya adalah hak dan kewajiban bagi siapapun (laki-laki dan perempuan) tanpa adanya perbedaan.Berdasarlan pemikiran itu, ia meyakini bahwa tidak adanya kekuatan bagi Hawa untuk menahan emosinya ketika dibujuk syetan, mengakibatkan ia mudah digelincirkan syetan. Bai Philo, perempuan secara alamiah memiliki sifat lebih terbuka kepada kesenangan fisik, membuat syetan berhasil menggodanya. Bahkan rasa rendah diri perempuan dianggap sebagai kaki tangan syetan. ${ }^{5}$

\section{B. Konsep Laki-laki dan Perempuan dalam Konstruksi Sosial}

Konsep laki-laki dan perempuan diartikan sebagai konstruksi sosiokultural yang membedakan karakteristik maskulin dan feminin. Gender berbeda dengan seks atau jenis kelamin laki-laki dan perempuanyang bersifat biologis. Walaupun jenis kelamin laki-laki sering diartikan erat dengan gender maskulin dan jenis kelamin

\footnotetext{
${ }^{4}$ M.Attiyah al-Abrashi. al-Tarbiyah al-Islamiyah, (Isababi al-Halabi, Mesir), 109.

${ }^{5}$ Fadhilah Suralaga\&Eri Rosatria (ed.), Perempuan : Dari Mitos ke Realitas (Jakarta: PSW UIN Jakarta McGill-ICIHEP, 2002), 49-50.
} 
326 | MUSA WA, Vol. 11 No. 2 Desember 2019 : 319 - 343

perempuan berhubungan dengan gender feminim.

Erniati mengatakan bahwa jenis kelamin merupakan alat analisis yang baik untuk menentukan fakta yang bertentangan dengan kaum perempuan secara umum. Ditegaskan bahwa gender adalah pembagian laki-laki dan perempuan yang dikonstruksi secara sosial dan budaya. Dan ternyata, perbedaan gender antara lakilaki dan perempuan terjadi melalui proses yang sangat panjang, melalui proses sosialisasi, penguatan, konstruksi sosial budaya melalui koordinasi negara. Sedimikian panjang dan lamanya proses genderisasi pada sosial budaya ini sehingga lebih cepat laun membedakan gender antara laki-laki dan perempuan sebagai konstruksi sosial menjadi sesuai dengan ketentuan tuhan, atau hanya kodrati dan biologis yang tidak dapat digunakan lagi. Artinya, ada anggapan sebagian besar masyarakat yang disebut kodrat wanita adalah hasil konstruksi sosial dan budaya atau gender. Gender memengaruhi manusia sebagai budaya masyarakat tentang bagaimana memajukan laki-laki dan perempuan berpikir dan bertindak sesuai dengan ketentuan sosial tersebut.

Masyarakat sebagai suatu kelompok, membuat pembagian gender untuk menentukan apa yang mereka anggap sebagai suatu persetujuan, untuk membedakan antara laki-laki dan perempuan. Misalnya, mendidik anak, merawat dan merawat rumah tangga, atau rumah tangga seperti perawatan, merawat anak kecil dianggap sebagai kodrati wanita. Pertanyaan yang menarik untuk dibaca lebih lanjut adalah: apakah perbeedaan jenis kelamin dapat diterima perbedaan gender? Persoalanpersoalan apa saja yang dihasilkan dari perbedaan gender? 
Gender artinya tipe atau jenis. Gender merupakan ciri-ciri peran dan tanggung jawab yang dibebankan pada perempuan dan laki-laki, yang ditentukan secara sosial dan bukan berasal da berubah0i pemberian Tuhan atau kodrat. Konsep gender adalah hasil konstruksi sosial yang diciptakan oleh manusia, yang sifatnya tidak tepat, dan berubah-ubah serta dapat dialihkan dan dipertukarkan menurut waktu, tempat dan budaya setempat dari satu jenis kelamin lainnya. Konsep gender juga termasun interk karakteristik atau ciri-ciri laki-laki dan perempuan yang diciptakan oleh keluarga dan atau masyarakat, yang dipengaruhi oleh budaya dan interpretasi agama. Misalnya pekerjaan memasak, mengurus anak, mencuci selalu disebutkan hanya sebagai pekerjaan perempuan. Pandangan seperti ini merupakan ciptaan masyarakat dari budaya tertentu, padahal pekerjaan tersebut dapat juga dipertukarkan dengan laki-laki atau dapat dikerjakan oleh laki-laki.

Kolaborasi dan "perselingkuhan" ideologis antara kekuatan patriarkhi yang diwariskan oleh peradaban kuno dan metafisika Barat, dapat dijelaskan sebagai berikut:

Patriarkhi mengurung mahluk laki-laki dan perempuan pada kotak-kotak identitas yang tertutup rapat antara satu dengan yang lain. Kompartmentalisas ini diperparah oleh pemaknaan identitas perempuan berdasarkan sudut pandang lakilaki. Perempuan didefinisikan secara sosial, oleh dan untuk kepentingan laki-laki. Identitas perempuan adalah mahluk yang bukan laki-laki. Jika misalnya laki-laki beridentitas rasional, maskulin dan publik, maka perempuan adalah beridentitas emosional, feminin, dan domestik. Konsepsi identitas ini kemudian mengarah pada 
328 | MUSA WA, Vol. 11 No. 2 Desember 2019 : 319 - 343

adanya dikhotomi, konsepsi kedua dari metafiska Barat.

Persekongkolan antara ideologi patriarkhi dan dikhotomi, terletak pada adanya dominasi satu pihak atas pihak lain, yang lahir dari dikhotomi ini. Kosekusesinya, relasi laki-laki dan perempuan merupakan relasi dominasi. Data historis para perempuan terdidik tersebut, memberikan legitimasi atas seruan nabi tentang pentingnya pendidikan bagi laki-laki dan perempuan. Sejarah memberikan fakta-fakta perempuan memiliki peran yang mewarnai berbagai dimensi kehidupan. Dengan demikian, profesioanlitas tidak bergantung dari sudut jenis kelamin tetapi ditentukan oleh kemampuan setiap individu. Berdasarkan kenyataan sejarah tersebut, maka perempuan (muslimah) tidak hanya cukup dengan belajar secara teoritis saja, namun harus mampu memanfaatkan dan mengaplikasikan dalam bidang kehidupan sebagai seorang yang profesional.

Pengakuan Islam atas hak perempuan dalam mengenyam pendidikan yang tiada batas. Ada kebebasan perempuan untuk belajar dari mulai pendidikan dasar sampai pendidikan tinggi, sesuai minat masing-masing individu perempuan. Pada dasarnya ruh pendidikan Islam adalah "kebebasan dan demokrasi" yang tidak memandangi jenis kelamin. Dengan asumsi bahwa setiap manusia (perempuan/laki-laki) mempunyai potensi yang harus diasah melalui pendidikan agar bermanfaat untuk membangun dunianya.

Perempuan harus membekali diri dengan ilmu sebagai pembuka cakrawala dan akhlak yang baik. Kesetaraan antara laki-laki dan perempuan dapat dilihat dari 
kemampuan dan ilmu pengetahuan yang dimiliki. ${ }^{6}$ Hal ini menunjukkan eksistensi seseorang. Peran pendidik perempuan dapat dimulai dari keluarga. Karena keluarga merupakan sekolah pertama bagi anak dan sekaligus tempat menimba ilmu, akhlak dan berbagai kecakapan hidup lainnya sebelum bersentuhan dengan dunia luar. Untuk mengokohkan kontribusi perempuan dalam pendidikan dapat dilihat dari syair sebagai berikut:

Ibu adalah sekolah jika engkau mempersiapkannya dengan baik maka sesungguhnya engkau telah mempersiapkan pemuda baik lagi tangguh di masa depan. $^{7}$

Pendidikan merupakan wahana pemberdayaan masyarakat dengan mengutamakan penciptaan dan pemeliharaan sumber yang berpengaruh, seperti keluarga, sekolah, media massa, dan dunia usaha. Prinsip pemberdayaan masyarakat dengan segenap institusi sosial yang ada di dalamnya, terutama institusi yang diletakkan dengan fungsi mendidik generasi penerus bangsa. Seperti: keluarga, sekolah dan berbagai wadah organisasi pemuda, diberdayakan untuk dapat mengembangkan fungsi pendidikan dengan baik serta menjadi bagian yang terpadu dari pendidikan. Prinsip kemandirian dalam pendidikan dan prinsip pemerataan menurut warga negara secara individual maupun kolektif untuk memiliki kemampuan bersaing dan sekaligus kemampuan bekerja sama. Islam memberikan hak kepada perempuan dalam pendidikan sebagai wujud untuk kemandirian, demokrasi dan keadilan superior yang dimiliki oleh identitas laki-laki, yakni rasional, maskulin, dan

\footnotetext{
${ }^{6}$ Ibid.

${ }^{7}$ Muhammad 'Attiyah al-Abrashi, op.cit, t.t 2000, h. 115.
} 
330 | MUSA WA, Vol. 11 No. 2 Desember 2019 : 319 - 343

petualang publik, dianggap merupakan kualitas, sifat dan perilaku yang melekat pada identitas tersebut. Kualitas rasionalitas dan maskulinitas laki-laki, diyakini lebih unggul dari kualitas emosionalitas dan feminitas perempuan. Konsekuenasi dari keyakinan ini adalah lahirnya klaim masyarakat patriarkhi bahwa sudah kodratnya, laki-laki memiliki posisi superior, dominatif, dan menikmati posisi-posisi istimewa dan sejumlah privelege lainnya atas perempuan.

Untuk melanggengkan superioritasnya, dominatifnya dan kekuatan privelegnya, laki-laki harus menekan emosinya dan menekan feminitasnya. Karena itu, dikatakan cengeng, jelek dan tidak wajar jika laki-laki menangis. Dikataan tabu kalau laki-laki berbicara lembut. Laki-laki dikontruksi harus kuat menahan tangis, tegas dalam berbicara dan bertindak, dan seterusnya.

Berdasarkan kolaborasi dan "perselingkuhan" kepentingan antara patriarkhi dan metafiskan barat yang melahirkan sejumlah keistimewaan posisi laki-laki dibanding perenpuan di atas, maka perlu adanya gerakan penyadaran tidak hanya terhadap perempuan tetapi juga terhadap laki-laki, bahwa patriarkhi sebagai sebuah ideologi yang mapan, ternyata dibangun di atas fondasi yang dikonstruksi oleh manusia. Kendati terkesan sosok patriarkhi yang demikian kokoh, sesungguhnya ia dibangun di atas pondasi yang goyah. Kesadaran kolektif bahwa identitas, dikhotomi dan kodrat yang selama ini dipahami sebagai sesuatu yang given dan absolut, sebenarnya tidak lebih dari sekedar buatan tangan manusia.

Identitas, dikhotomi dan kodrat, tidak lain adalah hasil dari proses hegemoni wacana budaya patriarkhi, yang dilanggengkan melalui sejumlah piranti sosial dan 
bahkan politik untuk mengokohkannya. Dalam konteks Indonesia misalnya bisa dilihat pendefinisian perempuan/isteri sebagai pendamping laki-laki/suami, dikokohkan oleh instritusi sosial berupa Dharma wanita. Demikian juga wacana mengenai posisi laki-laki/suami sebagai pemimpin, juga ditopang kuat oleh institusi agama.

Pandangan perempuan dan laki-laki, satu sama lain tentang diri mereka masing-masing merupakan pengkondisian yang dibentuk oleh masyarakat secara seksis. Pandangan dan konstruk yang seksis tersebut akan bertahan dan menyelubungi cara berfikir, baik terhadap perempuan maupun laki-laki. Dalam konteks seperti ini, mesti diingat bahwa kodrat yang melekat pada laki-laki dan perempuan adalah kuat, pengasih, pintar, antusias, kooperatif, tegas, percaya diri dan sensitif.

Jika semua laki-laki dan perempuan telah mengenal kodratnya yang sama, maka konsekuensiya kita harus menolak pandangan yang menyatakan bahwa anaklaki-laki pada dasarnya memang bersifat agresif. Adanya anggapan seperti itu, tidak lain hanyalah dikondisikan dan di-setting oleh situasi sosial yang ada. Laki-laki, sama dengan perempuan, juga memiliki emosi, sifat pengasih dan sensitivitas.

Untuk mengembangkan semua potensi kodrati laki-laki yang sesungguhnya sama dengan perempuan, perlu adanya dorongan kepada mereka untuk berlatih mengekspresikan diri secara alamiah. Sebagian besar pengkondisian sosial terhadap laki-laki, berasal dari paksaan sosial untuk bertindak sesuai aturan sosial yang biasa berjalan. Misalnya ketika laki-laki menangis, akan dikatakan cengeng seperti perempuan. Pengondisian seperti ini, pada akhirnya membuat laki-laki menerima 
332 | MUSA WA, Vol. 11 No. 2 Desember 2019 : 319 - 343

peran-peran yang tidak alamiah dan manusiawi, untuk dimainkan dalam kehidupan sosial mereka. ${ }^{8}$

Berdasarkan realitas pengkondisian sosial sehingga masyarakat, baik lakilaki maupun perempuan sendiri tidak memahami atau merasakan bahwa semua itu merupakan produk sosial, maka penghapusan seksisme yang berimplikasi sangat luas dalam kehidupan harus dijadikan sebagai fokus utama perjuangan untuk menegakkan keadilan gender. Hal ini karena, semua perilaku yang menimbulkan segala bentuk ketidak-adilan gender, sepereti marjinalisasi, subordinasi, kekerasan, steterotipe dan peran ganda bagi perempuan, salah satunya berakar mendalam pada ideologi seksisme yang menjadi penopang kuat ideologi patriarkhi.

Pembagian kerja secara seksual, seringkali dikonstruksi berdasarkan gender. Kegiatan-kegiatan ekonomis cenderung terklasifikasikan menurut jenis kelamin. Beberapa peran dilihat melulu sebagai maskulin atau feminin. Namun fakta semakin menguatkan bahwa peran sosial laki-laki dan perempuan merupakan hasil konstruksi masyarakat, sehingga akibatnya sebuah peran yang di suatu tempat dianggap maskulin di tempat lain dianggap feminin. Memasak misalnya, hanya dilakukan oleh perempuan dalam 158 masyarakat. Sebaliknya perkayuan hanya dilakukan oleh lakilaki dalam 104 masyarakat. Berburu, menangkap ikan, membuat senjata dan perahu cenderung menjadi tugas laki-laki, sementara menumbuk padi dan mengambil air menjadi tugas perempuan.

\footnotetext{
${ }^{8}$ Veven Sp. Wardhana, “ Puanografi dan Media: Yang Bukan perempuan (Tak) Ambil Bagian”, dalam Nur Iman Subono, Feminis Laki-laki, 90.
} 
Sementara kegiatan yang berganti-ganti dikerjakan oleh laki-lakiu dan perempuan adalah mengolah tanah, menanam, merawat dan memanen. Dalam masyarakat tertentu, laki-laki sangat berpengaruh pada pengasuhan anak. Kegiatan tersebut tidak dianggap sebagai wilayah kerja perempuan. Sebut saja misalnya dalam suku Arapesh di Papua Newgini, yang beranggapan bahwa mengandung dan melahirkan anak merupakan tugas bersama suami-isteri, sehingga mereka dibebaskan dari tugas-tugas klan lainnya. Suku Aboriogin di Australia dan kepulauan Tobriand di Papua Newgini meyakini bahwa mengasuh anak adalah merupakan tugas penting ibu maupun ayah. ${ }^{9}$

Mengacu kepada perbedaan kebudayaan yang berakibat pada perbedaan peran laki-laki dan perempuan di atas, dapat dikatakan bahwa pembagian tugas dan kerja tidaklah bergantung pada jenis kelaim tertentu, tetapi peran merupakan khas setiap kebudayaan, dan karenanya gender adalah juga khas untuk setiap kebudayaan. Karena itu juga, gender tidak hanya berbeda antar kebudayaan yang berbeda, tetapi juga berbeda dari waktu ke waktu dalam kebudayaan yang sama. Kebudayaan bukanlah sesuatu yang statis, tetapi berkembang seiring dengan berlakunya waktu dan berjalannya sejarah. Dengan berkembangnya masyarakat, peran-peran yang dijalani oleh perempuan dan laki-laki tidak lagi hanya ditentukan oleh kebudayaan, tetapi juga oleh ideologi yang dominan pada suatu masa dan oleh faktor-faktor sosial, politik dan

9 Ivan A. Hadar, "Feminisme, Feminis Laki-laki dan Wacana Gender Dalam Upaya Pengembangan Masyarakat", dalam Nur Iman Subono,Feminis Laki-laki, 93-111. 
334 | MUSA WA, Vol. 11 No. 2 Desember 2019 : 319 - 343

ekonomi. ${ }^{10}$

\section{Patriarkhi dan Kontrol Sosial terhadap Perempuan}

Kendati patriarkhi memberikan kontribusi besar bagi pelanggengan dominasi laki-laki atas perempuan, sebenarnya sistem ini juga membatasi ruang gerak laki- laki, yang "dipaksa" selalu harus tampil rasional, maskulin dan petualang publik. Namun demikian, dibanding "penderitaan" laki-laki yang diakibatkan oleh ideologi ini, keuntungan yang dirasakan laki-laki lebih besar. Pada saat yang sama, ideologi ini sama sekali tidak memberikan keuntungan bagi perempuan. Sebaliknya, ia diciptakan untuk melakukan kontrol sosial terhadap perempuan, baik kontrol terhadap tubuh maupun peran sosial perempuan. Warisan keagamaan kuno hingga modern, tampaknya juga memberikan kotribusi besar bagi pengontrolan tubuh dan sosial perempuan tersebut.

Sistem teologi agama kuno yang menggambarkan sosok tuhan-tuhan yang banyak, kemudian diseleksi pada gambaran-gambaran tuhan yang berpengaruh, hingga kepercayaan monotheisme, memberikan gambaran Tuhan sebagai sosok bapak yang perkasa, sebagaimana dalam sistem teologi Kristiani misalnya, merupakan proses sekunderisasi perempuan.

Secara historis, munculnya ideologi patriarkhi berasal dari mesopotamia Kuno pada zaman neolitikum, seoring dengan munculnya negara-negara kota. Bahkan menurut para femnis, munculnya hegemoni laki-laki atas perempuan, sesunguhnya

${ }^{10}$ Ibid. 
terjadi jauh sebelum era neolitikum yang menandai lahirnya negara- negara kota tersebut.

Antara tahun 3500-3000 SM, di Mesopatamia bermunculan negara-negara kota. Kondisi ini mengakibatkan adanya peranan militer dan politik terhadap hegemoni. Hal ini memperkuat dominasi laki-laki atas perempuan, sehingga menimbulkan adanya stratifikasi sosial pada masyarakat. Sistem keluarga patriarkhi yang memastikan penyampaian warisan dari ayah kepada anak laki-laki, dan pengontrolan seksualitas perepmuan menjadi melembaga. Hal ini kemudian terekam ke dalam hukum dan kemudian mendapat legitimasi dan dukungan dari institusi politik maupun negara.

Dalam konteks di atas, seksualitas perempuan menjadi aset dan kekayaan laki-laki, pertama milik ayah dan kedua milik suami. Kesucian seksualitas perempuan memperoleh nilai ekonomi, yang bisa dijadikan modal tawar menawar. Tampaknya budaya seperti ini juga terserap dalam praktik keagamaan di dunia Islam. Uang jemputan dalam kasus peminangan perempuan Makassar atau perempuan Aceh, merupakan contoh konkritnya, di mana harga perawan ditentukan oleh status sosial ayah-nya.

Kemunculan negara-negara kota pada zaman Mesopotamia Kuno, menyebabkan ditinggalkannya perempuan sebagai pekerja. Akibatnya kondisi ini semakin menjauhkan perempuan dalam "petualangan" publik, yang bisa dihargai secara ekonomis. Dengan demikian, pengisolasian perempuan dari bursa kerja negara-negara kota, mengurangi kontribusi mereka dalam akses ekonomi. Kondisi ini 
336 | MUSA WA, Vol. 11 No. 2 Desember 2019 : 319 - 343

semakin memperkuat sekunderisasi perempuan, bahkan lebih jauh merendahkan status perempuan.

Kondisi pengotrolan dan pembatasan gerak perempuan dalam konteks masyarakat Mesopotamian, semakin ditopang oleh aturam negara, berupa Undangundang Hamurabi (1750 SM), yang dibuat atas nama dewa Perang, Marduk. Sekali lagi perlu dipahami bahwa peperangan merupakan simbol hegemonik dari petualangan laki-laki. Kendati dalam banyak hal merugikan perempuan, kode Hammurabi masih memberikan sedikit hak kepada perempuan. Misalnya dikatakan bahwa bagi laki- laki yang menceraikan isteri-isterinya, diharuskan membayar ganti rugi. Aturan ini berbeda dengan Undang-undang Assyiria (1200 SM), yang membatalkan hak-hak perempuan sebagai ibu. Hak itu diberikan kepada suami, yang belum tentu ia berikan kepada isterinya yag dicerai. Misalnya dinyatakan dalam ayat 183, bahwa bila laki- laki menceraikan isterinya, ia bisa memberikan sesuatu kepada isterinya bila ia mau, jika ia tidak mau memberikan sesuatu kepada isterinya, maka isterinya pergi dengan tangan kosong. ${ }^{11}$

Dalam konteks Mesopotamia kuno, sumber kekuatan dan kekuasaan berada di tangan ayah dan suami. Perempuan dan anak-anak harus patuh kepada kekuasaan mutlak mereka. Dalam Undang-undang Hamurabi dinyatakan bahwa kepala keluarga berhak mengatur perkawinan ank-anaknya. Ia bisa mengirim anak- anak perempuannya ke candi untuk menjadi biarawati. Ia bisa menggadaikan istri dan anak-

\footnotetext{
${ }^{11}$ Fatmagul Berktay," Ciri Khusus Patrarkhi: Kontrol Sosial terhadap Tubuh Perempuan", dalam Suralaga\&Rosatria (ed.), Perempuan: dari Mitos, 1-39
} 
anaknya untuk membayar hutang-hutangnya.

Tidak berbeda dengan Hamurabi, Assyiria juga menyatakan bahwa bila seorang suami memperkosa perempuan lain, maka perbuatan itu akan mengotori istrinya. Karena itu ia harus mnceraikan istrinya.jika terjadi pemerkosaan atas gadis oleh laki-laki lajang, maka laki-laki tersebut harus membayar harga gadis tersebut kepada ayahnya dan mengawininya. Dengan demikian, perempuan sama sekali tidak memiliki otonomi dan independensi atas dirinya.

\section{Perempuan dan Simbolisasi Kontrol Sosial}

Penggunaan cadar bagi perempuan terutama di kawasan jazirah Arab, terpengaruh oleh Undang-undang Asyiria. Dalam undang-undang tersebut, dibedakan secara jelas perempuan yang berhak dan tidak berhak menggunakan cadar. Cadar merupakan simbol bagi kesucian dan keperawanan perempuan. Simbol ini juga menjadi pertanda adanya perempuan yang berada di bawah perlindungan laki-laki, dan perempuan "bebas" yang bisa menjadi "mangsa" seksual bagi siapapun.

Dalam konteks masyarakat arab, budaya ini digunakan untuk membedakan antara hurrah dan 'amat. Hurrah adalah para perempuan terhormat yang hidupnya di bawah perlindungan laki-laki terhormat. Sedangkan 'amat merupakan perempuanperempuan pekerja seksual, yang tidak memiliki pelindung seorang laki-laki. Perintah berjilbab bagi para perempuan, juga terkait dengan budaya masyarakat Arab yang sebelumnya tidak ada perbedaan antara hurrah dan amat tersebut. ${ }^{12}$

\section{${ }^{12}$ Ibid}


338 | MUSA WA, Vol. 11 No. 2 Desember 2019 : 319 - 343

Menurut Lerner, sebagaimana dikutip Fatmagul Bertaky, menyatakan bahwa dengan demikian, cadar tidak saja merupakan simbol kelas atas, tetapi lebih penting lagi, ia merupakan simbol yang membantu membedakan antara perempuan yang bisa dinikmati oleh banyak laki-laki, dengan perempuan yang hanya bisa dinikmati oleh satu laki-laki dan hidup berada di bawah perlindungannya. ${ }^{13}$

Dengan demikian, pemakaian cadar dan kerudung atau penutup kepala, sesungguhnya tidak saja merupakan tradisi Islam, tetapi telah ada jauh sebelum Islam datang. Dalam tardisi Kristen, pemakaian kerudung atau penuup kepala telah dlakukan oleh St. Paul untuk membangun satu bagian pelembagaan Kristen. Dalam agama Yahudi, Yunani dan Byzantium yang berada dalam peradaban Laut Tengah bagian Timur, cadar melibatkan arti sosial yang semakin kompleks. Namun demikian, dalam tardisi agama-agama dunia, tradisi cadar atau kerudung dan penutup kepala, lebih terasa khas dalam trdisi Islam dibanding dalam tradisi agama-agama selainnya.

\section{E. Perkawinan: Agama dan kontrol laki-laki tehadap perempuan}

Pada abad pertama Masehi, satu-satunya wilayah efektif bagi perempuan Yahudi adalah pada lingkungan keluarga. Pembatasan peran perempuan diasosiasikan dengan tradisi perkawinan di era itu. Kekuasaan seorang ayah atas anak perempuan mereka dan kekuasaan suami atas siterinya, demikian luar biasa. Semua hukum tentang perkawinan, kewarisan dan perceraian, kemudian dikonstruksi dengan berpihak kepada kaum lai-laki. Sedikit sekali peraturan hukum yang menetralkan atau

\footnotetext{
${ }^{13}$ Ibid
} 
mengimbangi kontrol dan kekuasaan ayah dan suami. Seseorang bisa menyebutkan bahwa "uang cerai" yang harus dibayarkan oleh suami kepada isterinya yang diceraikan. Namun di sisi lain anak perempuannya yang belum dikawinkan, memiliki hak untuk mengikuti ayahnya. Dengan demikian, sekali lagi, nilai ekonomis anak perempuan, berpulang kepada ayahnya.

Dengan sejumlah elaborasi pada beberapa aspek, tampaknya hukum Islam juga mengadaptasi atau minimal dipengaruhi oleh agama Yahudi dalam hal perkawinan, perceraian dan hak waris. Misalnya dalam Perjanjian Lama dinyatakan bahwa ibu patut mendapatkan penghormatan sama dengan penghormatan terhadap ayah. Bahkan menurut Mishnah dan Talmud, dua kitab pegangan komunitas Yahudi, perempuan juga memiliki hak untuk menikmati kesenangan seksual. Demikian juga dalam soal kewarisan. Perempuan Yahudi memiliki hak untuk mendapatkan harta kekayaan, dan ia diberi hak untuk memiliki bagian dari warisannya, meskipun prioritasnya diberikan kepada anak laki-laki.

Dalam tradisi agama-agama monoteisme, terdapat praktik keagamaan yang meminggirkan perempuan, yang tampaknya juga diwariskan secara turun-temurun. Dalam konteks Yahudi misalya, kendati pada awalnya perempuan diberi kesempatan untuk melakukan peribadatan pada kuil yang sama dengan laki-laki, pada tahap berikutya hak tersebut dirampas. Mereka hanya diberikan hak untuk melakukan peribadatan dalam kuil yang terpisah dengan laki-laki. Praktik semacam ini telah ada di era pemerintahan Trajan di Yerussalem, sejak abad $2 \mathrm{M}$. 
340 | MUSA WA, Vol. 11 No. 2 Desember 2019 : 319 - 343

Warisan peribadatan semacam ini, juga bisa ditemukan dalam tradisi Kristiani. Perempuan dilarang berbicara di gereja. St. Paul menunjuk tentang hal ini dalam surat pertamanya kepada Corinthians: "Biarkan perempuan-perempuan kamu tetap diam ketika mereka berada di gereja, karena mereka tidak diizinkan berbicara; mereka diperintah untuk patuh dan begitu pula hukum memerintah mereka untuk patuh. Bila mereka ingin belajar apasaja, biarkan mereka meminta atau menanyakannya kepada suami mereka. Adalah memalukan bagi perempuan untuk berbicara di gereja (Corinthians, 14: 34-35).

Perintah yang terdapat dalam naskah Corinthians yang diperoleh dari St Paul ini equivalen dengan ide bahwa laki-laki adalah pemimpin perempuan. Kontrol atas perempuan yang sangat dikenal dengan tubuh merupakan analog mengenai kontrol terhadap gereja yang merupakan tubuh Kristus.

Larangan bagi perempuan untuk berbicara di gereja, dipahami dari bab 15 Kitab Leviticus, yang menyebutkan bahwa pendeta yang melakukan sesajian atau persembahan kepada Tuhan harus dalam keadaan bersih. Dalam konteks ini, perempuan dianggap tidak bersih ketika mengalami menstruasi. Karena itu, perempuan dilarang berbicara di gereja karena dengan "kekotorannaya" berarti ia tidak bisa melaksanakan kewajiban agamaya. Lagi-lagi, dalam ritual-pun, perempuan dianggap tidak memiliki porsi yang sama dengan laki-laki, ia dianggap berkurang agamanya dari laki-laki. 
Tampaknya kepercayaan akan kekurangan agama perempuan juga terilfiltrasi dan tertransfer ke dalam tradisi Islam. Bahkan dalam salah satu Hadits Nabi, dinyatakan bahwa perempuan memiliki dua kekurangan, yakni kekurangan pada akal dan agamanya. ${ }^{14}$

Margareth Mead, ${ }^{15}$ menyatakan bahwa dikhotomi seka ada pada setiap masyarakat. Perbedaan biologis antara perempuan dan laki-laki, tidak secara otomatis menciptakan ketidaksetaraan di antara keduanya, yang oleh Francoise Heritier dinyatakan bahwa implikasi ketidaksetaraan dimaksud meresap ke semua aspek kehidupan.

Senada dengan tesis di atas, pendapat Aristoteles bahwa perempuan adalah laki-laki yang kurang, dan kepercayaan bahwa Hawa bertanggung jawab atas dosa warisan dan pengusiran Adam dari Surga, juga semakin mendukung pelembagaan patriarkhi, metafora dasar dan simbol-simbol peradaban bahwa peremuan lebih redah dari laki-laki. Implikasinya lebih jauh adalah, munculnya dua konsep mengenai manusia, yakni: konsep laki-laki dan konsep perempuan yang secara hirarkhi berbeda bentuk, fungsi dan potensinya. Dalam konteks iniulah, tubuh yang tidak saja dianggap sebagai teks kebudayaan, merupakan fokus kontrol sosial yang praktis, sebagamana didefinisikan oleh Bourdeu dan Foucoult.

\footnotetext{
${ }^{14}$ Lihat Masdar Farid Mas'udi, Islam dan Hak-hak Reproduksi Perempuan (Bandung: Mizan, 2001), 42.

${ }^{15}$ Fatmagul Berktay, "Dikhotomi Antara Jiwa dan Tubuh: Masalah Polarisasi di dalam Diri Manusia", dalam Suralaga\&Rosatria (ed), Perempuan: Dari Mitos, 42
} 
342 | MUSA WA, Vol. 11 No. 2 Desember 2019 : 319 - 343

\section{KESIMPULAN}

Peran laki-laki dan perempuan, terutama yang terikat dalam perkawinan, sesungguhnya bisa dibedakan dari dua teori peran laki-laki dan perempuan yang berlawanan, yaitu teori nature dan teori nurture. Jika teori nature mengatakan bahwa perbedaan peran gender bersumber dari perbedaan seks/biologis laki-laki dan perempuan, maka teori nurture mengandaikan bahwa perbedaan peran gender antara laki-laki dan perempuan bukan merupakan konsekuensi dari perbedaan biologis yang kodrati, namun lebih sebagai hasil konstruksi manusia. Konstruksi dimaksud sangat dipengaruhi oleh kondisi sosio-kultural yang melingkupinya.

Teori peran laki-laki an perempuan, tentusaja juga tidak bisa dilepaskan dari teori filsafat yang menyangganya. Misalnya Plato yang memposisikan perempuan rendah, namun ia masih menyisakan tempat bagi perempuan, untuk menembus kesejatian laki-laki. Demikian juga Aristoteles yang mendukung ide dikhotomi jiwaraga., dengan anggapan ketidaksetaraan di antara manusia sebagai sesuatu yang alami dan bahwa yang kuat harus mendominasi yang lemah. Jika Plato melihat dunia sebagai proses oposisi kembar yang tiada hentinya, Aristoteles juga mengandaikan bahwa dualisme hirarkhi, yakni oposisi kembar mengharuskan adanya dominasi satu pihak atas pihak lainnya. Jiwa mendominasi tubuh, akal mendominasi perasaan, lakilaki mendominasi perempuan dan seterusnya.

Tradisi agama-agama yang berakar pada tradisi Mesopatmia Kuno, yang menginfiltrasi pemikiran agama Yahudi, Kristen dan Islam, terdapat mekanisme 
pelembagaan dan penetapan patriarkhi yang mengontrol tubuh perempuan. Hal ini tentu saja berimplikasi pada kontrol sosial-budaya terhadap peran perempuan. Gambaran mengenai pandangan agama-agama yang terkesan "mendiskreditkan" perempuan, dapat dilihat pada tradisi agama-agama Timur maupun Barat.

\section{DAFTAR PUSTAKA}

Adian, Donny Gahral.” Feminis Laki-laki Sebagai Seni Pengambilan Jarak", dalam Nur Iman Subono (ed.) Feminis Laki-laki: Solusi Atau Persoalan. Jakarta: Yayasan Jurnal Perempuan- The Japan Foundation, 2001.

Aristotels, Politics. Istambul: Remzi Publishing House, 1983.

Berktay, Fatmagul. "Ciri Khusus Patrarkhi: Kontrol Sosial terhadap Tubuh Perempuan", dalam Suralaga\&Rosatria (ed.), Perempuan: dari Mitos, 1-39.

--."Dikhotomi Antara Jiwa dan Tubuh: Masalah Polarisasi di dalam Diri Manusia", dalam Suralaga\&Rosatria (ed), Perempuan: Dari Mitos.

Hadar, Ivan A. "Feminisme, Feminis Laki-laki dan Wacana Gender Dalam Upaya Pengembangan Masyarakat", dalam Nur Iman Subono, Feminis Laki-laki Solusi Atau Persoalan. Jakarta: Yayasan Jurnal Perempuan- The Japan Foundation, 2001.

Hein, Hidle. "Liberating Philisophy: An End to the Dichotomy of Spirit and Matter," eds. dalam Ann Gary dan Marlyn Persall, Women, Knowledge and Reality. London: Unwin Hyman, 1989.

Mas'udi Masdar Farid, Islam dan Hak-hak Reproduksi Perempuan. Bandung: Mizan, 2001.

Suralaga, Fadhilah \&Eri Rosatria (ed.), Perempuan : Dari Mitos ke Realitas. Jakarta: PSW UIN Jakarta - McGill-ICIHEP, 2002.

Wardhana, Veven Sp. "Puanografi dan Media: Yang Bukan perempuan (Tak) Ambil Bagian”, dalam Nur Iman Subono, Feminis Laki-laki Solusi Atau Persoalan. Jakarta: Yayasan Jurnal Perempuan- The Japan Foundation, 2001. 